son Committee chaired by Joan Chambers, to make contacts with other higher education associa- tions and to work cooperatively in bringing librarians into the mainstream of academia.

\title{
Baltimore '86
}

\section{Baltimore epitomizes "Energies for Transition."}

\section{$\mathbf{P}$} resent day Baltimore is changing dramatically in its race to prepare for the electronic, high-tech future to which the Baltimore-Washington corridor seems destined. The planning committee for the Fourth National ACRL Conference is just putting together the program, but it is not too early to think about visiting Baltimore and its environs. Baltimore is a city of the future, but its past is still visible to the casual observer. The energy of Baltimoreans has fueled a succession of urban transformations over the city's long history. Hence, Baltimore epitomizes the theme chosen for the ACRL Conference, "Energies for Transition," which is to be held at the Convention Center April 9-12, 1986.

\section{History}

The City Leaders are fostering attempts to learn from the past and to preserve outstanding achievements of earlier times. Baltimoreans recognize the truth of what John Dos Passos said of this city in 1968:

"Some day the prime movers who decide our destinies may come to understand that the character of a city as a fit place for men and women to live depends on the survival of intriguing vestiges of the past."l

Witness four inner-city archaeological digs in recent months and the $\$ 11$ million late 1970 s restoration of the 1875 City Hall with its magnificent rotunda and dome.

Only a hamlet in 1750 , by the early nineteenth century Baltimore was considered a large city. From mid-century to the end of the nineteenth cen-

\footnotetext{
${ }^{1}$ John Dorsey and James D. Dilts, A Guide to Baltimore Architecture (2d ed., Centreville, Md.: Tidewater, 1981), p. xv.
}

tury, Baltimore doubled its population again. One can now easily spot from atop Federal Hill or the World Trade Center the geographical featuresthe Piedmont fall line to the West and the sheltered harbor on the East-which provided the energy and outlet for Baltimore's productivity. The city's maritime and industrial heritage is depicted well in the Baltimore Museum of Industry, one of the newest of our city's forty plus museums and galleries.

Called the northernmost Southern city in the country, Baltimore shared in the strengths of both regions. In the thriving nineteenth century, three of the four Baltimoreans who gave their names to world-renowned city institutions were Yankees. Enoch Pratt (of library fame), born in Massachusetts, augmented his already considerable fortune by controlling the horseshoe and mule-shoe business during the Civil War. By 1830 George Peabody, also from Massachusetts, was the senior partner of the largest mercantile house in the country. In 1857 he set about creating the Peabody Conservatory, long the center of Baltimore's musical life, and the Peabody Library, now under the control of Johns Hopkins University. Hopkins was the native Marylander of the four, while the other Yankee was William T. Walters, originally from Pennsylvania, whose collecting penchant eventually resulted in the Walters Art Gallery. The Peabody is one of the cornerstones of Mount Vernon Place, the square surrounding Robert Mill's monument to George Washington, finished in 1829. Mount Vernon and nearby beautiful squares were home to many prominent families, some of old Maryland stock. Baltimore looked to the South for guidance in the matters of cookery, hospitality, and the social conventions generally. Henry James once called these squares of Mount Vernon "the parlour 


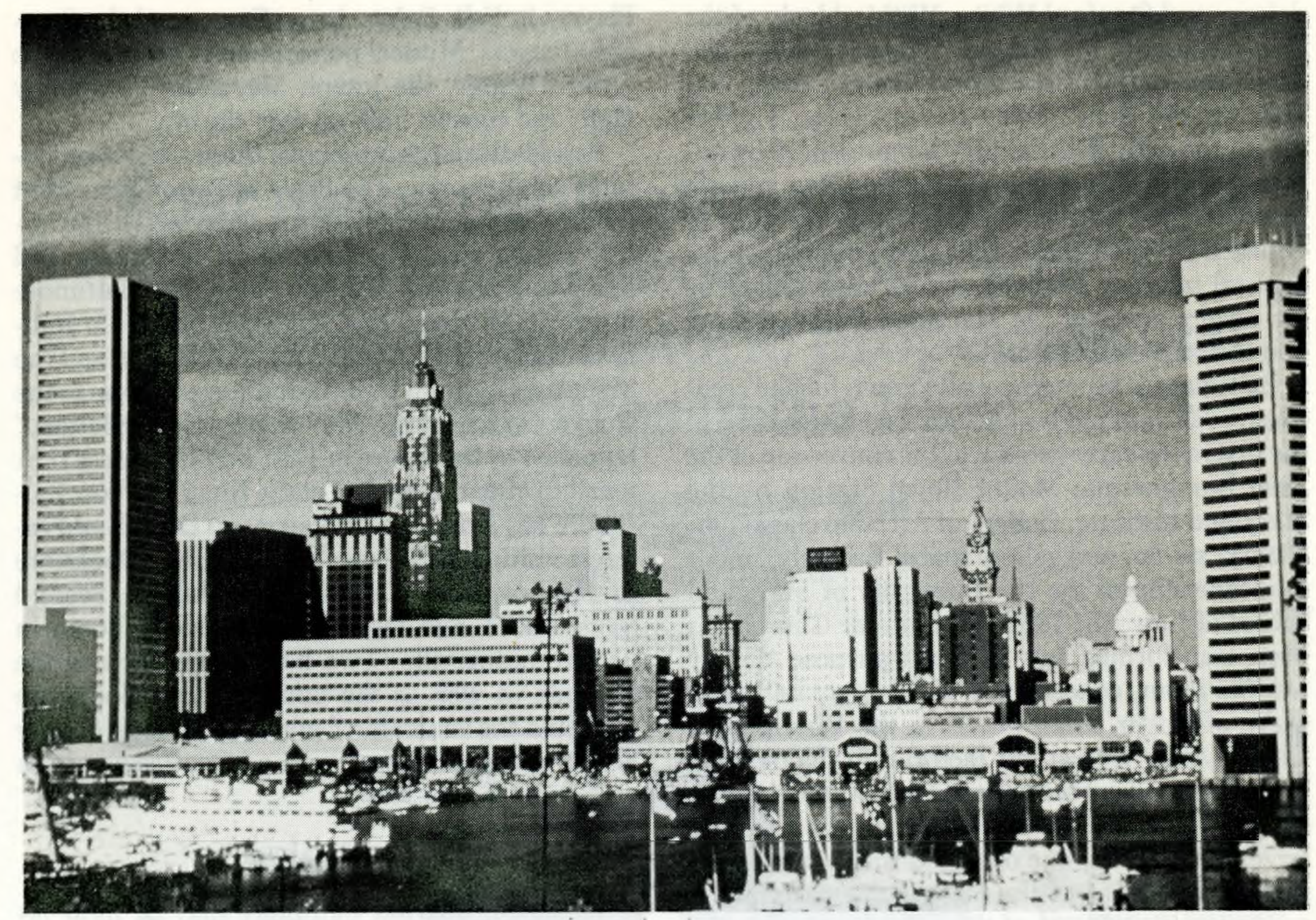

Baltimore’s Inner Harbor.

Cr: Baltimore Convention Bureau

of Baltimore." The qualities of gracious living, pride in tradition, and comfortable formality suggested by James's phrase still permeate much of life in Baltimore.

\section{Modern transformations}

Baltimore has needed its energy, for it has had to virtually recreate itself twice in this century. It quickly recovered from the disastrous fire of 1904 , which destroyed 2,000 buildings over 140 acres in the heart of downtown. Baltimore's modern renaissance started in the early 1960s when Charles Center became the hub of the downtown, with the cultural center north of it, the shopping center to the west along Howard Street, and the financial and government center to the east. In the 1970s the redevelopment spread to the south in connection with the Convention Center and boom in entertainment, shopping, and hotel construction near the harbor. More than a dozen hotels have been finished recently or are under construction, and there is a four-fold increase in the rate of building new offices. This revitalization has been accomplished with a mix of private, Federal, State, and City money.

The present mayor, William Donald Schaefer, as a member of the City Council in 1964 spearheaded the enactment of the One Percent Ordinance that requires $1 \%$ of the cost of construction or renovation of City-owned buildings to be spent for the installation of art in public places. Also in 1964 , in response to plans to destroy dozens of his- toric buildings in the Mount Vernon area, the City government made a commitment to preserve the city's historic past by creating the Commission for Historical and Architectural Preservation (CHAP). CHAP has helped transform decaying neighborhoods into areas of attractive restored housing. There are now 23 historic districts in the city, ranging from small clusters of houses for workers to the magnificent townhouses of Bolton Hill and the planned garden suburb of Roland Park. Part of this transformation has been fostered by urban homesteading, for which Baltimore has become famous. Interspersed with housing in these districts and geared to walking are many fine specialty shops and restaurants, serving a wide variety of ethnic foods.

\section{Architectural ambience}

Baltimore boasts many notable buildings with some of the oldest and the newest within walking distance of the Convention Center. Right next to that facility is the Otterbein Church (now affiliated with the United Methodist Church) built in 1785 and recently restored; it is the only 18 thcentury church in continuous use in Baltimore. Davidge Hall of the University of Maryland's Medical School, designed in 1812 by Robert Cary Long, Sr., is the oldest medical school building in the country. The city has numerous other outstanding 19th-century buildings designed by the Latrobes (whose papers are being edited for publication at the Maryland Historical Society), Maximilian Go- 
defroy, and Stanford White. Within blocks of the Conference site are Edward Durrell Stone's Science Center, I.M. Pei's World Trade Center, and Mies van der Rohe's One Charles Center. Farther afield, the early 20 th century is represented by numerous parks which follow stream valleys and are based on 1904 and 1926 reports from the firm of Olmsted Brothers. Even the latest nostalgic architectural interest, art deco, is well represented by the headquarters of the Maryland National Bank and the Senator Theater.

Baltimore is becoming well known for the creative recycling of old buildings for new uses. One of the first in the early sixties was the conversion of the 1896 Romanesque Mount Royal Station by the Maryland Institute, College of Art, into classroom, library, studio, and gallery space. Recently, under the leadership of the the University of Maryland School of Law, the 1852 Westminster Church has been transformed into a multi-purpose library reading room, concert hall, and lecture hall. The grave of Edgar Allan Poe is in the Westminster Churchyard. Several loft factories in the old garment district have been turned into apartments or condominiums. This also has happened to two large high schools, one of which is near the top of Federal Hill. One of the most highly anticipated conversions, on Pier 4 of the Inner Harbor, is the Six Flags Power Plant urban entertainment complex, which will blend Victorian splendor with space-age technology, and which is due to open this spring. The Power Plant is next to the acclaimed National Aquarium that everyone visits. One of the major new structures visible as one enters downtown on Interstates 95 or 395 is Baltimore's Southwest Resource Recovery Facility, which is transforming the metropolitan area's refuse into energy (electricity and steam heat), instead of filling up landfills. These efforts highlight the creativity in conserving natural resources and preserving the built environment, energizing both the economic and social fabric of a great city.

\section{Things to do}

April is an inviting month to sample the Londonlike quality of the many and diverse neighborhoods that make up Baltimore. The city in April is likely to have warm, sunny days and crisp, cool nights. The normal daily maximum temperature is 65 , and there is relatively little rain in April. The Conference planners are building some breaks into the schedule in order to permit Conference goers to do things on their own. It would be well worth spending a few days before or after the Conference getting to know Baltimore and vicinity. April in Baltimore will provide Orioles Baseball, Blast Indoor Soccer, racing at Pimlico, and the Bullets Basketball at Largo's Capital Center near Washington. In April of 1986 the city will host the seventeenth International Film Festival. Live theater is plentiful at Center Stage, the Mechanic Theatre, and numerous smaller companies, such as the Vagabond
Players in Fells Point, Arena Stage, and the Spotlight Players. Musical performances abound at the Lyric Theater, the Joseph Meyerhoff Symphony Hall, and concert halls all over the city.

Besides the large museums, there are several notable smaller ones. The Peale Museum, the oldest public museum in the country, is devoted to the history of the city. The Babe Ruth Birthplace and Maryland Baseball Hall of Fame, the Baltimore Streetcar Museum, the Baltimore and Ohio Railroad Museum, the Edgar Allan Poe House, and the Mencken House on Union Square are all close to the Convention Center. The "U.S.S. Constellation," launched in Baltimore in 1797 and the oldest U.S. warship afloat, is docked at the Inner Harbor. Baltimore has a number of bookstores that should interest visiting librarians: the Children's Bookstore in Harborplace, Kelmscott Bookshop, Second Story Books, and Drusilla's (children's) Books in nearby Lutherville. Two book shops cater to the stomach as well as the mind: Louie's Bookstore Cafe and the venerable Peabody Bookshop \& Beer Stube-a haunt of Mencken and Dos Passos-both on North Charles Street.

\section{Good eating}

This leads to what Baltimore may be most famous for-good eating. From long established restaurants, such as Haussner's in Highlandtown and Marconi's, tucked away on Saratoga Street, to the newest craze in eating (this being mesquite cookery), there are hundreds of places to eat in Baltimore. Most tourists have heard of lunching at the Lexington Market, but the Cross Street and the Hollins Street Markets, also within walking distance of the Convention Center, would provide a more authentic taste of neighborhood life. Seafood is king in Baltimore, from Phillips Harborplace Restaurant to Connolly's Seafood House along the Pratt side of the Inner Harbor to Obrycki's Crab House, a mile farther East on Pratt Street. Other unusual places to lunch within walking distance are the diner of Diner movie fame, recently deposited between the City Hall and the City Archives, the International Culinary Arts Institute, the Women's Industrial Exchange, and the Owl Bar in the Belvedere Hotel. Or follow the aroma of spice to McCormick \& Co. on Light Street for a tour and then a respite in their charming Tea Room. Little Italy, just to the East of the Inner Harbor, has the highest concentration of outstanding ethnic restaurants in the city. But almost every other nationality is represented somewhere in the city.

\section{Charm city}

Academic librarians are grappling with how to deal with high technology and constrained resources while preserving what is good about traditional collection development and user services. Come to Baltimore in April 1986 for the Fourth National ACRL Conference, "Energies for Transi- 


\section{Four major publications which are now the single largest source of information on historic properties and structures in the USA}

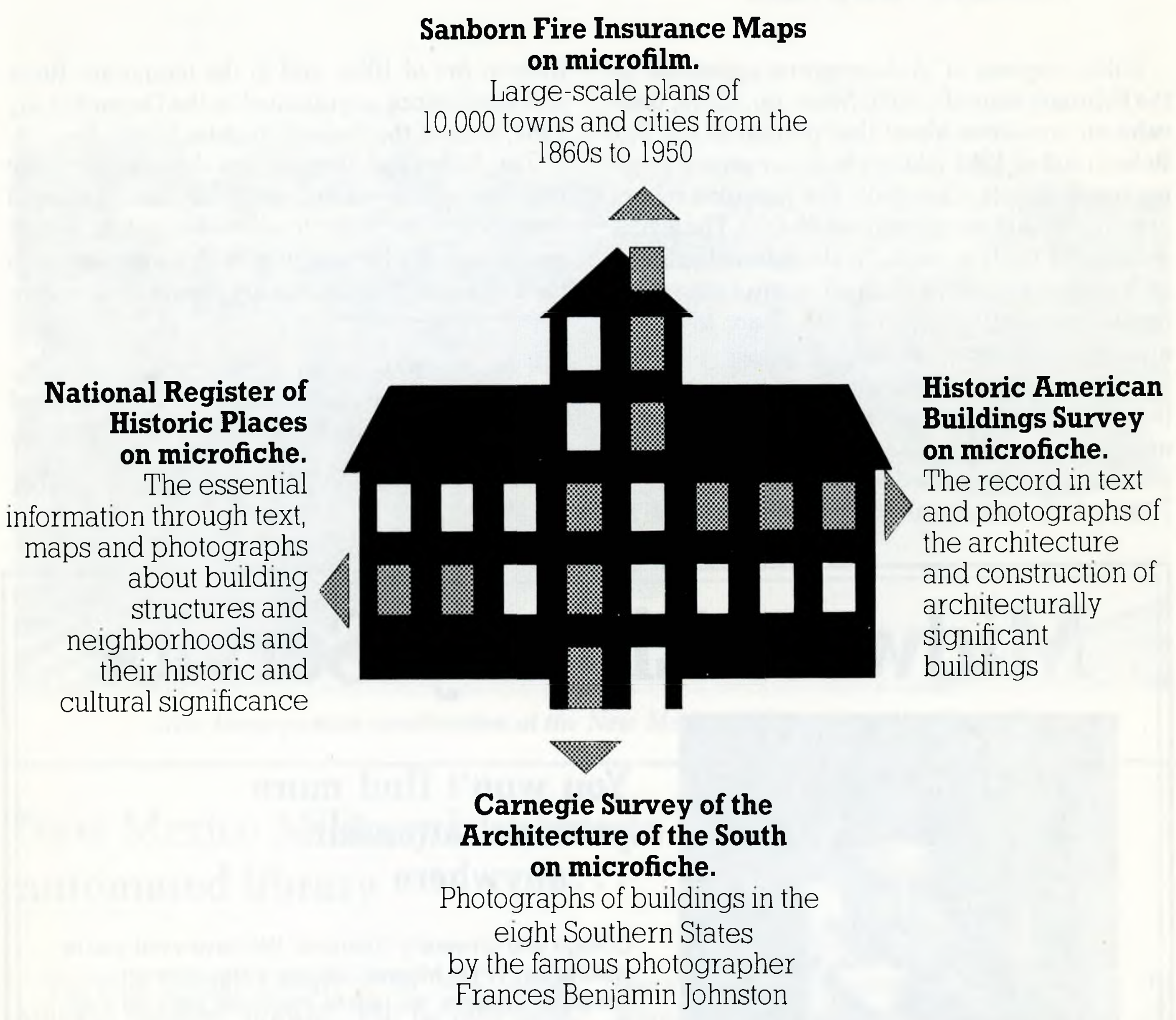

These reference works are primary sources for architectural, urban, social and local historians and for geographers, dernographers, genealogists and archaeologists - and for everyone who is interested in the history of their neighborhood.

For descriptive brochures, prices and sample microfiche, please call Linda Fox on (201) 692-1801

\section{Chadwyck-Healey Inc.}

623 Martense Avenue, Teaneck, NJ 07666 
tion." We promise that the intellectual stimulus of the Conference will match the excitement of Baltimore, known to its enthusiasts as "Charm City." In
1986 be charmed by all that Baltimore has to offer the mind and the senses.

\title{
A closer eye on appraisals: A clarification
}

\author{
By John R. Payne \\ Assistant to the Director \\ Harry Ransom Humanities Research Center \\ University of Texas at Austin
}

Public response to "A closer eye on appraisals" in the February issue of $C \& R L$ News, pp.52-56, indicates an uneasiness about that portion of the Tax Reform Act of 1984 relating to donee record keeping requirements. Essentially this provision relates only to gifts that are valued over $\$ 5,000$. The actual wording of the law reads: "if the claimed value of such property (plus the claimed value of all similar items of property donated by the donor to one or more donees) exceeds $\$ 5,000$."

The new federal regulations must be interpreted through reference to two separate U.S. Government publications: 1) The law as described in Conference Report on the Deficit Reduction Act of $1984^{\mathrm{I}}$ which contains all the provisions of the Tax
Reform Act of 1984; and 2) the temporary Rules and Regulations as published in the December 31, 1984, issue of the Federal Register. ${ }^{2}$

The Rules and Regulations describe how the new law will be carried out. They are considered "temporary" in order to allow for public review and comment. Persons who wish to comment on the Rules and Regulations are encouraged to con-

1"“The Tax Reform Act of 1984," Conference Report on the Deficit Reduction Act of 1984: Federal Taxes, Prentice-Hall Bulletin 29 Extra, June 29, 1984.

${ }^{2}$ Federal Register, Vol. 49, No. 252 (December $31,1984)$.

\section{Midwest Library Service}

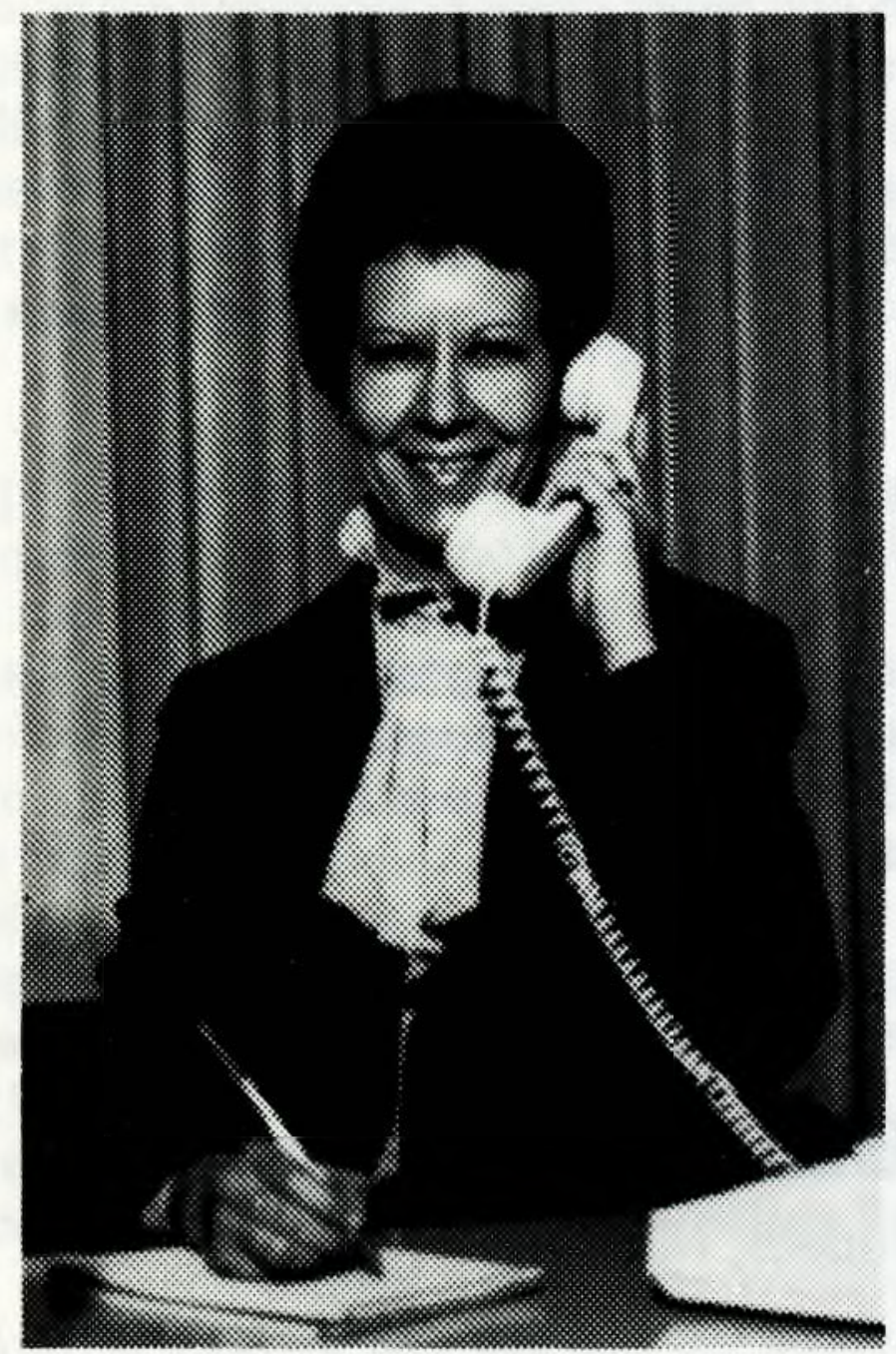

\section{You won't find more personal attention ... anywhere}

College and university librarians: We have what you're looking for. While Midwest utilizes state-of-the-art computer systems, we realize machines can't do it all. So when you want to place an order, ask a question, or discuss a problem, you can call direct on Midwest's toll-free WATS line and conduct business on a nameto-name basis with your personal customer service representative. It's the kind of attention that Midwest has provided to college and university libraries for 24 years.

Call toll-free (800) 325-8833

Missouri librarians call toll-free (800) 392-5024 Canadian librarians call collect (314) 739-3100 